\title{
Determinants of Apartment Prices within Housing Estates of Nairobi Metropolitan Area
}

\author{
James N. Ndegwa ${ }^{1}$ \\ ${ }^{1}$ School of Business and Economics, The Cooperative University of Kenya, Kenya \\ Correspondence: James N. Ndegwa, Lecturer, Accounting and Finance Department, School of Business and \\ Economics, The Cooperative University of Kenya, Kenya. E-mail: jndegwa@cuk.ac.ke
}

Received: April 2, 2018

Accepted: April 26, 2018

Online Published: May 10, 2018

doi:10.5539/ijef.v10n6p104

URL: https://doi.org/10.5539/ijef.v10n6p104

\begin{abstract}
The objective of this study is to establish the determinants that significantly influence apartment prices that are located within housing estates of Nairobi metropolitan area. The determinants comprise of apartments features including: proximity to shopping malls, proximity to Nairobi's central business district, proximity to schools, proximity to slums, presence of swimming pool, presence of balcony, size of the apartment, periodic rental income and land value. Both secondary and primary data sources were employed in the research and 30 housing estates where apartment are located were selected for data collection purposes. Multiple regression analysis was employed for the secondary data and the findings indicated that: land value and size of the apartments had a significant influence on apartment pricing. Descriptive statistical analysis findings indicated that proximity to shopping malls, proximity to Nairobi's central business district, proximity to schools, presence of swimming pool, size of the apartments and land value had significant influence on apartment prices. Triangulation of secondary and primary data analysis results indicated a consistency rate of $50 \%$. The recommendation of the study is that real estate stakeholders especially buyers should focus on size and land value of apartments as these significantly influence apartment pricing in Nairobi metropolitan area.
\end{abstract}

Keywords: apartments, determinants, prices, size and land value

\section{Background of the Study}

In the real estate market the value of a property composed of the property's price or rent income. Property valueis made up of the property price and rent and are influenced by the forces of demand and supply just like other economic resources (Brueggenan \& Fisher, 2011). Living in housing estate apartments as opposed to other types of housing like mansionettes or bungalows is a growing concept in the real estate market of Nairobi. This is attributable to the householders demand for housing with unique amenities in addition to placing importance on security (Kenya Bankers Association, 2016). The developers and real estate agents are keen to portray the benefits of estate apartments in order for home buyers and tenants to pay a premium for such benefits which include socialization, security and common services like cleaning, gym and landscaping (Muiga \& Rukwaro, 2016).

Both the public and the government is concerned about the rising housing prices in Nairobi and efforts have been made to build low cost housing for majority of the residents of the city who cannot afford the current houses on offer (Kenya Bankers Association, 2016). The Kenyan government recently formed of the Kenya Mortgage Refinancing Company amid other efforts to cater for housing units that are affordable to the masses flowing to Nairobi city which may be triggered by rural to urban migration.

The numerous studies that have been done globally have provided mixed findings regarding the determinants of housing prices (Candas, Kalkan, \& Yomralioglu, 2015; Chung, 2012; Amenyah \& Afenyi, 2013; Aluko, 2011). The motivation of the current research is thus to assess the determinants of apartment prices in Nairobi city.

\section{Research Objective}

To assess factors influencing estate apartments prices in Nairobi County.

\section{Research Hypothesis}

$H_{0}$ : There is no significant relationship between each of the factors and prices of estate apartments in Nairobi 


\section{metropolitan area.}

\section{Literature Review}

There are mixed findings regarding the determinants of housing prices according to the numerous studies carried out globally. Candas, Kalkan, and Yomralioglu, (2015) carried out a study in Istanbul Turkey and examined the determinants of house prices in and employed location features, presence of elevators, the floor in case of apartments, heating systems, land value and rent income value. The study used 116 valuation reports and employed multiple regression analysis data analysis method and established that the floor the apartment was located alongside the presence of heating system, the land value and rent value had significant influence on the price of the house. The focus of the current study would be to compare whether the significant determinants of housing prices in other regions of the world like Turkey would also be applicable in Nairobi.

Chung (2012) studied the determinants of residential property prices in Hong Kong using a cointegration analysis approach. The study focused on house sizes that ranged from very small of below $40 \mathrm{M}^{2}$ to the very large size of above $160 \mathrm{M}^{2}$. The study established that average annual rent income, excess liquidity, Hong Kong stock market index, real interest rates significantly influenced average price of residential houses. The study focused on macroeconomic determinants unlike the study by Candas, Kalkan, and Yomralioglu, (2015); Amenyah and Afenyi, (2013); Aluko, (2011). Chung. (2012) study also differs from the current which focuses on housing features as the determinants of apartment prices in Nairobi Metropolitan area. From the above two studies the first research hypothesis in alternative form was developed as follows:

$\mathrm{H}_{1}$ : There is a significant relationship between the prices of estate apartments in Nairobi metropolitan area and their related sizes, land value and rental income value.

Amenyah and Afenyi, (2013) carried out a study in Accra Ghana on factors determining residential rental prices. The involved 100 households and it employed the Chi-square technique to assess the association between determinants and house prices in Accra. The findings were that location, size of the house, connection to utility facilities appeared to have significant influence on house rent prices. The study focused on low cost housing units and had determinants relating to connection to utilities unlike the current research which focuses on determinants of pricing of estate apartments in Nairobi where connection to utilities would automatically be in place. From this research the second hypothesis in alternative form was developed as follows:

$\mathrm{H}_{2}$ : There is a significant relationship between the prices of estate apartments in Nairobi metropolitan area and their related location features including: proximity to shopping malls, schools, slum and Nairobi CBD areas.

Aluko, (2011) studied the effects of location and neighborhood features on housing values in metropolitan Lagos. Locational features included: proximity to workplace, schools, shopping, recreation and worship centers. Neighborhood features included: crime levels, noise levels and the cost of refuse collection. Structural features included: area of land occupied by building, number of rooms in the house, number of persons per house, number of kitchens, bathrooms and open spaces per house. Multiple regression analysis was employed and the study found that neighborhood and locational features significantly influence on house values when small housing units were examined. From this research the third hypothesis in alternative form was developed as follows:

$\mathrm{H}_{3}$ : There is a significant relationship between the prices of estate apartments in Nairobi metropolitan area and the structural features of apartment including: presence of a balcony and swimming pool.

\section{Research Methodology}

\subsection{Research Design}

Mixed research design was employed in this research which comprised of quantitative and qualitative research designs. The quantitative design was to cater for the secondary data that was in numerical form while the qualitative designs was to cater for the primary data that was in the form of perceptions drawn from apartment residents using a questionnaire (Creswell, 2014).

\subsection{Population and Sampling}

There is no official list of apartments in Nairobi metropolitan area and hence 30 residential estates that contain 3 bed-roomed apartments were selected for the research as indicated in Appendix 2.

\subsection{Data Collection}

A cross section approach was employed in data collection where data was collected for 30 apartments and 150 residents at a single point in time (Creswell, 2014). Secondary data was drawn from the internet websites that 
indicated sale or rent of the 30 residential apartments as indicated in Appendix 2. Primary data in the form of 150 self-administered 3 point likert scale closed ended questionnaire was administered to residents of the 30 residential apartments to the residents using convenient sampling technique.

\subsection{Data Analysis}

Data was analyzed by employing a multiple regression analysis model as was the case in the previous relevant studies by Candas, Kalkan, and Yomralioglu (2015) and Aluko (2011). The dependent variable was apartment price while the independent variables included: proximity to shopping malls, proximity to Nairobi's central business district, proximity to schools, proximity to slums, presence of swimming pool, presence of balcony, size of apartment, periodic rental income and land value.

The multiple regression model was as follows (Gujarati, 2006):

$$
Y=\beta_{0}+\beta_{1} X_{1}+\beta_{2} X_{2}+\beta_{3} X_{3}+\beta_{4} X_{4}+\beta_{5} X_{5}+\beta_{6} X_{6}+\beta_{7} X_{7}+\beta_{8} X_{8}+\beta_{9} X_{9+} e
$$

Where:

$\mathrm{Y}=$ apartment's price (Kenya shillings);

$\mathrm{X}_{1}=$ Proximity to shopping malls (kilometers);

$\mathrm{X}_{2}=$ Proximity to Nairobi's central business district - CBD (kilometers);

$\mathrm{X}_{3}=$ Proximity to schools (kilometers);

$\mathrm{X}_{4}=$ Proximity to slums (kilometers);

$\mathrm{X}_{5}=$ Presence of swimming pool (dummy variables $0 / 1$ );

$\mathrm{X}_{6}=$ Presence of balcony (dummy variables $0 / 1$ );

$\mathrm{X}_{7}=$ Size of apartment - Floor area (square meters);

$\mathrm{X}_{8}=$ Periodic rental income or value (Kenya Shillings);

$\mathrm{X}_{9}=$ Land value (Kenya Shillings);

$\mathrm{e}=$ error term;

$\beta=$ coefficients;

$\beta_{0}=$ constant.

\section{Secondary Research Findings}

\subsection{Reliability Test Results}

Reliability of the research instrument was assessed using Cronbach Alpha and the findings were presented in Table 1 indicated Cronbach Alpha of 0.743 which was greater than 0.7 threshold of reliable data which indicated that the data was reliable (Gliem \& Gliem, 2003).

Table 1. Reliability test results

\begin{tabular}{cc}
\hline Cronbach's Alpha & N of Items \\
\hline .743 & 10 \\
\hline
\end{tabular}

\subsection{Validity}

A scale is deemed as valid if it measures the specific concept it is supposed to measure (Creswell, 2014). In this research the variables and methods employed had been employed by researchers in the past including Candas, Kalkan and Yomralioglu (2015) and Aluko (2011).

\subsection{Normality Test Results}

When normality test were carried out the findings as per Figure 1 indicated a p-value of 0.6058 which was higher than 0.05 at $95 \%$ level of significance. This implied that the null hypothesis of normality of the data was not rejected and hence parametric tests could be carried out in this research (Gujarati, 2004). 


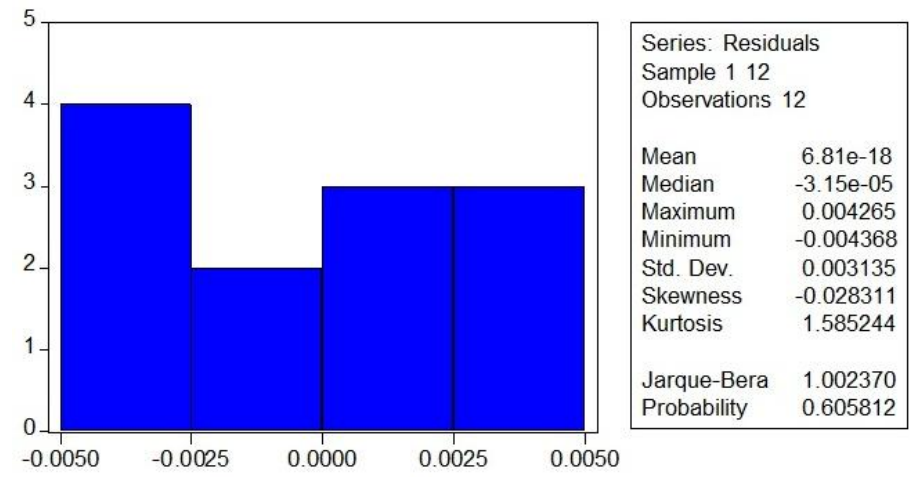

Figure 1. Normality test results

\subsection{Serial Correlation Test Results}

The problem of serial correlation in the data was tested using Breusch-Godfrey Serial Correlation LM Test as indicated in Table 2. The null hypothesis of no serial correlation was rejected as the observed R-Squared p-value was 0.821 which was higher than 0.05 at $95 \%$ level of significance (Vogelvang, 2004).

Table 2. Breusch-Godfrey serial correlation LM test

\begin{tabular}{llll}
\hline F-statistic & 0.11965 & Probability & 0.88793 \\
Obs*R-squared & 0.393602 & Probability & 0.821354 \\
\hline
\end{tabular}

\subsection{Homoscedasticity Test Results}

The problem of heteroscedaticity in the data was tested using White test as indicated in Table 3 . The null hypothesis of homoscedasticity was not rejected as the observed p-value was 0.256 which was higher than 0.05 at $95 \%$ level of significance. This implied that the data did not have the problem of heteroscedaticity (Vogelvang, 2004).

Table 3. White Heteroskedasticity test

\begin{tabular}{llll}
\hline F-statistic & 1.453443 & Probability & 0.251024 \\
Obs*R-squared & 19.24289 & Probability & 0.256269 \\
\hline
\end{tabular}

\subsection{Multi-collinearity Test Results}

The variance inflation factor findings which are below the threshold of 10 except the VIF for rental value which was above 10 and was eliminated from the analysis as a solution as indicated in Table 4.

Table 4. Variance Inflation Factors (VIF)

\begin{tabular}{lcc}
\hline & Tolerance values & Variance Inflation Factors (VIF) \\
\hline Proximity to shopping malls & 0.705349 & 1.417737 \\
Proximity to Nairobi CBD & 0.214433 & 4.66347 \\
Proximity to schools & 0.334679 & 2.987941 \\
Proximity to slums & 0.260089 & 3.844834 \\
Proximity to swimming pool & 0.228546 & 4.375488 \\
Presence of a balcony & 0.148878 & 6.716903 \\
Size of apartment & 0.179021 & 5.585946 \\
Land value & 0.311683 & 3.208385 \\
\hline
\end{tabular}

The multicollinearity results are supported by those of the correlation matrix in Table 5 which indicated correlation coefficients of less than 0.75 which implies that the independent variables were not correlated (Hair et al., 2006). 
Table 5. Correlation matrix

\begin{tabular}{|c|c|c|c|c|c|c|c|c|c|c|}
\hline & & $\begin{array}{l}\text { Near } \\
\text { malls }\end{array}$ & $\begin{array}{c}\text { Nairobi } \\
\text { CBD }\end{array}$ & $\begin{array}{c}\text { Near } \\
\text { school }\end{array}$ & $\begin{array}{l}\text { Near } \\
\text { slum }\end{array}$ & $\begin{array}{l}\text { Near } \\
\text { pool }\end{array}$ & $\begin{array}{c}\text { With } \\
\text { balcony }\end{array}$ & Size & $\begin{array}{c}\text { Rental } \\
\text { value }\end{array}$ & $\begin{array}{l}\text { Land } \\
\text { value }\end{array}$ \\
\hline Near malls & Pearson Correlation & 1 & & & & & & & & \\
\hline Nairobi CBD & Pearson Correlation & .145 & 1 & & & & & & & \\
\hline Near schools & Pearson Correlation & .072 & -.126 & 1 & & & & & & \\
\hline Near slums & Pearson Correlation & -.212 & -.087 & .093 & 1 & & & & & \\
\hline Near pool & Pearson Correlation & -.271 & -.136 & .306 & $.485^{* *}$ & 1 & & & & \\
\hline With balcony & Pearson Correlation & .041 & $-.446^{*}$ & .150 & -.085 & .277 & 1 & & & \\
\hline Size & Pearson Correlation & -.250 & $-.551^{* *}$ & -.010 & .220 & .335 & $.401^{*}$ & 1 & & \\
\hline Rental value & Pearson Correlation & -.206 & $-.473^{* *}$ & .121 & .315 & $.598^{* *}$ & $.418^{*}$ & $.701^{* *}$ & 1 & \\
\hline Land value & Pearson Correlation & -.120 & $-.393^{*}$ & .278 & .324 & $.365^{*}$ & .193 & $.394^{*}$ & $.645^{* *}$ & 1 \\
\hline
\end{tabular}

Note. *. Correlation is significant at the 0.05 level (2-tailed); **. Correlation is significant at the 0.01 level (2-tailed).

\subsection{Adjusted R-Square Results}

The adjusted $\mathrm{R}$ - square results indicated that the determinants could explain $52.06 \%$ of the movement in apartment property prices while the rest of the movement could be explained by other factors as per Table 6 .

Table 6. $\mathrm{R}$-square results model summary

\begin{tabular}{ccc}
\hline R Square & Adjusted R Square & Std. Error of the Estimate \\
\hline 0.6529 & 0.5206 & 0.024431 \\
\hline
\end{tabular}

\subsection{ANOVA Results}

The findings on joint influence of the determinants on the dependent variable property price indicated that the independent variables were not jointly significantly influential on the property price as per Table 7 with p-value being 0.001549 which was more than 0.05 at $95 \%$ level of significance.

Table 7. ANOVA results

\begin{tabular}{cc}
\hline F & Sig. \\
\hline 4.938021 & 0.001549 \\
\hline
\end{tabular}

\subsection{Regression Analysis Results}

The multiple regression results indicated that land value where the apartment is located and size of the apartment had a significant influence on apartment prices as they had a t-statistics of 2.7335 and 2.0674 which were greater than critical $t$ of 1.96 at $95 \%$ level of significance as per Table 8 .

Table 8. Regression analysis results

\begin{tabular}{lcccc}
\hline Dependent Variable: apartment price & & & & \\
\hline Variables & Coefficient & Std. Error & t-Statistic & Prob. \\
\hline C & -0.07099 & 0.035318 & -2.00985 & 0.0575 \\
Proximity to shopping malls & 0.032768 & 0.201035 & 0.162998 & 0.8721 \\
Proximity to Nairobi CBD & 0.091451 & 0.252611 & 0.362023 & 0.721 \\
Proximity to schools & -0.27138 & 0.220762 & -1.22931 & 0.2326 \\
Proximity to slums & 0.037657 & 0.274206 & 0.137329 & 0.8921 \\
Proximity to swimming pool & 1.081537 & 0.609388 & 1.774793 & 0.0904 \\
Presence of a balcony & 0.211744 & 0.593482 & 0.356782 & 0.7248 \\
Size of apartment & 1.633638 & 0.79017 & 2.067452 & 0.0512 \\
Land value & 0.312128 & 0.114186 & 2.7335 & 0.0124 \\
\hline
\end{tabular}

\section{Primary Data Research Findings}

\subsection{Response Rate and Characteristics of the Respondents}

Out of the 150 questionnaires distributed to residents of estate apartments being studied, 122 were filled which constituted $61 \%$ response rate. The characteristics of the respondents were as follows: in terms of gender of the residents of the apartments $42 \%$ of the respondents were male and $58 \%$ were female. In terms of the number of occupants per apartment $19 \%$ have 1 to 2 occupants, $58 \%$ of have 3 to 5 occupants, $21 \%$ of the have 6 to 8 
occupants, and only $2 \%$ have more than 8 occupants.

\subsection{Resident Perspectives on the Factors Influencing Apartment Prices in Nairobi}

According to the residents of sampled apartments using a 3 point likert scale all the factors had significant influence except for proximity to slum areas and presence of balcony in the apartments. The size in terms of floor area of had the most influence on the apartment pricing as per Table 9.

Table 9. Perceptual determinants of apartment prices

\begin{tabular}{llcc}
\hline S/N & apartment Features & Average Rating (out of 3) & Degree of influence on apartment Prices \\
\hline 1 & Proximity to Nairobi CBD & 2.4 & Significant \\
2 & Proximity to schools & 2 & Significant \\
3 & Proximity to shopping malls & 2.4 & Significant \\
4 & Proximity to slum areas & 1.9 & Not Significant \\
5 & Presence of swimming pool & 2 & Significant \\
6 & Presence of balcony & 1.8 & Not Significant \\
7 & Size of apartment & 2.8 & Significant \\
8 & Land value & 2.5 & Significant \\
\hline
\end{tabular}

\subsection{Triangulation of Findings from Primary and Secondary Data Sources}

The findings of secondary and primary data analysis were triangulated and the results were a consistency rate of $50 \%$ with 4 out of 8 determinants having a consistent effect on the apartment prices in Nairobi metropolitan area as per Table 10 .

Table 10. Triangulation of findings from primary and secondary data sources on attribute influence on apartment price

\begin{tabular}{lllll}
\hline S/N & apartment Features & Secondary data & Primary data & Consistency of the 2 data sets \\
\hline 1 & Proximity to Nairobi CBD & Not Significant & Significant & Inconsistent \\
2 & Proximity to schools & Not Significant & Significant & Inconsistent \\
3 & Proximity to shopping Mall & Not Significant & Significant & Inconsistent \\
4 & Proximity to slum & Not Significant & Not Significant & Consistent \\
5 & Presence of swimming pool & Not Significant & Significant & Inconsistent \\
6 & Presence of balcony & Not Significant & Not Significant & Consistent \\
7 & Size of apartment & Significant & Significant & Consistent \\
8 & Land value & Significant & Significant & Consistent \\
\hline
\end{tabular}

\section{Discussions}

From the findings of the current research, the determinants that have significant influence on apartment price include size of the apartment, the rental value and land value where the apartment is built. These findings are consistent with those of Candas, Kalkan and Yomralioglu, (2015) who found that these 3 factors had significant influence on house prices in Turkey.

\section{Recommendations}

Stakeholders interested in establishing the prices of estate apartments in the Nairobi metropolitan area should focus on the 2 key influential factors of size of the apartment and the surrounding land values.

\section{References}

Aluko, O. (2011). The Effects of Location and Neighborhood Features on Housing Values in Metropolitan Lagos. Ethiopian Journal of Environmental Studies and Management, 4(2), 69-88. https://doi.org/10.4314/ejesm.v4i2.8

Amenyah, I. D., \& Afenyi. E. F. (2013). Factors Determining Residential Rental Prices. Asian Economic and Financial Review, 3(1), 39-50. Retrieved from http://aessweb.com/journal-detail.php?id=5002

Brueggenan, W. B., \& Fisher, J. D. (2011). Real Estate Finance and Investments (14th ed.). McGraw Hill Irwin, New York, USA. Retrieved from https://www.amazon.com/Estate-Finance-Investments-McGraw-Hill.../dp/0073377333

Candas, E., Kalkan, S. D., \& Yomralioglu, T. (2015). Determining the Factors Affecting Housing Prices in Turkey. FIG Working Week 2015, From the Wisdom of the Ages to the Challenges of the Modern World, 
Sofia, Bulgaria, $\quad$ 17-21 $\quad$ May $2015 . \quad$ Retrieved $\quad$ from https://www.fig.net/.../fig.../fig2015/...TS08J_candas_bagdatli_kalkan_et_al_7868.pd...

Chung, K. H. (2012). Determinants of Residential Property Prices in Hong Kong: A Cointegration Analysis. International Research Journal of Finance and Economics, (96), 55-62. Retrieved from https://pdfs.semanticscholar.org/5ef9/0b3da8b51922273dc7ba02cc1b00a6853800.pdf

Creswell, J. W. (2014). Research Design: Quantitative, Qualitative and Mixed Methods Approach (4th ed.). Washington DC, USA: SAGE Publishers.

Gliem, J. A., \& Gliem, R. R. (2003). Calculating, Interpreting and Reporting Cronbach's Alpha Reliability Coefficient for Likert Scale Types. Midwest Research to Practice Conference. Retrieved from https://scholarworks.iupui.edu/bitstream/handle/1805/344/gliem+\&+gliem.pdf?...1

Gujarati, D. N. (2006). Essentials of Econometrics (4th ed.). McGraw Hill, Boston, USA. Retrieved from https://himayatullah.weebly.com/uploads/5/3/4/0/53400977/gujarati_book.pdf

Hair, J. F., Black, W. C., Babin, B. J., Anderson, R. E., \& Tatham, T. L. (2006). Multivariate Data Analysis, $6^{\text {th }}$ Edition, New Jersey. Pearson Education International. Retrieved from http://www.scirp.org/(S(lz5mqp453edsnp55rrgjct55))/reference/ReferencesPapers.aspx?Ref

Kenya Bankers Association. (2016). Housing Price Index. Retrieved from http://www.kba.co.ke/research-center/housing-price-index

Muiga, J. G., \& Rukwaro, R. W. (2016). Satisfaction of Residents with Gated Community Lifestyle: the Case of Nairobi County; Kenya. BEST: International Journal of Humanities, Arts, 4(12), 85-104. Retrieved from ir-library.ku.ac.ke/.../Satisfaction\%20of\%20Residents\%20with\%20Gated\%20Commun

Vogelvang, B. (2004). Econometrics: Theory and Applications with E-views. Harlow, England: Pearson Education Publishers.

\section{Appendix 1. Sample Questionnaire}

1. Name of the estate apartment you reside in:

2. Your name (optional):

3. Your gender

$\square$ Male

$\square$ Female

4. Please tick the number of people live in the house

$\square 1-2$

3-5

6-8

More than 8

5. To what extent do you think the following features influenced the price of the apartment you reside in? (please tick appropriately)

\begin{tabular}{|l|l|l|l|l|}
\hline S/N & apartment Attribute & $\begin{array}{l}\text { (1) No influence on } \\
\text { apartment price }\end{array}$ & $\begin{array}{l}\text { (2) Moderate Influence on } \\
\text { apartment price }\end{array}$ & $\begin{array}{c}\text { (3) Great influence on } \\
\text { apartment price }\end{array}$ \\
\hline 1 & Proximity to Nairobi CBD & & & \\
\hline 2 & Proximity to Schools & & & \\
\hline 3 & Proximity to Shopping Mall & & & \\
\hline 4 & Proximity to Slum Dwelling & & & \\
\hline 5 & Presence of swimming pool & & & \\
\hline 6 & Presence of Balcony & & & \\
\hline 7 & Size of housing & & & \\
\hline 8 & Landscaping & & & \\
\hline 9 & Rental income & & & \\
\hline 10 & Land value & & \\
\hline
\end{tabular}




\section{Copyrights}

Copyright for this article is retained by the author(s), with first publication rights granted to the journal.

This is an open-access article distributed under the terms and conditions of the Creative Commons Attribution license (http://creativecommons.org/licenses/by/4.0/). 